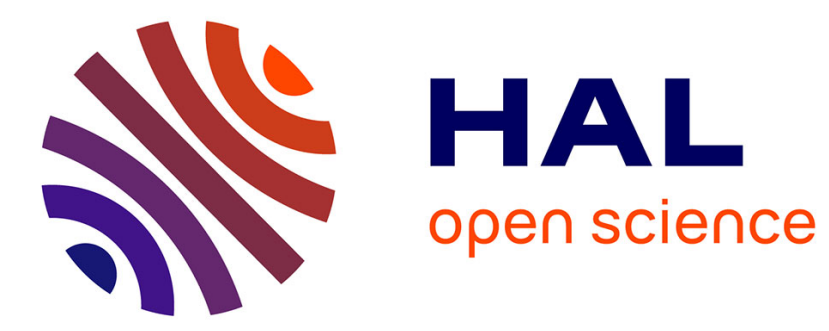

\title{
Long-, Mid- and Short-Term Evolution of Coastal Gravel Spits of Brittany, France
}

Pierre Stéphan, Serge S. Suanez, Bernard Fichaut

\section{To cite this version:}

Pierre Stéphan, Serge S. Suanez, Bernard Fichaut. Long-, Mid- and Short-Term Evolution of Coastal Gravel Spits of Brittany, France. G. Randazzo; D. Jackson; A. Cooper. Sand and Gravel Spits, 12, Springer, pp.275-288, 2015, Coastal Research Library, 10.1007/978-3-319-13716-2_15 . hal-01146229

\section{HAL Id: hal-01146229 \\ https://hal.science/hal-01146229}

Submitted on 28 Apr 2015

HAL is a multi-disciplinary open access archive for the deposit and dissemination of scientific research documents, whether they are published or not. The documents may come from teaching and research institutions in France or abroad, or from public or private research centers.
L'archive ouverte pluridisciplinaire HAL, est destinée au dépôt et à la diffusion de documents scientifiques de niveau recherche, publiés ou non, émanant des établissements d'enseignement et de recherche français ou étrangers, des laboratoires publics ou privés. 


\title{
Long-, mid- and short-term evolution of coastal gravel spits of Brittany, France
}

Pierre Stéphan, Serge Suanez and Bernard Fichaut

\author{
P. Stéphan $(\bowtie)$ \\ Laboratoire de Géographie Physique - UMR 8591 CNRS, \\ Universités Paris 1 Panthéon Sorbonne et Paris 12 \\ 1 Place Aristide Briand, 92195 Meudon cedex, France \\ e-mail: pierre.stephan@cnrs-bellevue.fr \\ S. Suanez - B. Fichaut \\ LETG-Géomer-Brest, UMR 6554 CNRS, \\ Institut Universitaire Européen de la Mer, Université de Brest, \\ Technopôle Brest-Iroise, Place Nicolas Copernic, 29280 Plouzané, France \\ e-mail: serge.suanez@univ-brest.fr, bernard.fichaut@univ-brest.fr
}

\begin{abstract}
Gravel spits of Brittany have experimented a long morphosedimentary evolution over the last millenia. Based on analysis of several back-barrier holocene sediment stratigraphies, distinct phases of construction and barrier breakdown were recognized, indicating the role played by storminess and sediment supply during the late-holocene period. Over the last centuries and decades, a deficit of sediment bubget affecting several gravel spits is highlighted. Therefore, actual coastal evolution of most of them is mainly dominated by cannibalization, landward retreat by rollover and complete destruction of the spits in some places. This coastal erosion is related to the lack of significant offshore sediment input or from the erosion of unconsolided cliffs. Locally, anthropogenic forcing have axacerbated the erosion processes by sediment minings and/or the construction of hard defense structures. For the swash-aligned gravel spits, frequency and magnitude of overwash processes is controlling the rate of landward retreat by rollover. This morphodynamic behaviour is illustrated by topomorphological surveys realised between 2002 and 2012 on Sillon de Talbert spit which has experienced a complete crestal removal during the 10 March 2008 Johanna storm. Although this event have a 50-100yrs occurence, the barrier has exhibited a rapid crestal rebuilding by overtopping processes, illustrating the great resilience of the spit. Thus, coastal erosion management strategies mainly based on hard defense structures are gradually abandoned for new management policies based on soft operations. Nowadays, gravel spits of Brittany are also considered as a geological heritage and management plans are establishing by local authorities.
\end{abstract}

\section{GENERAL SETTING}

In Brittany, gravel beaches are located mainly on the northern and western coast (fig. 1). Their construction is mainly due to the shoreward removing of periglacial deposits initially accumulated on the coastal shelf during the post-glacial marine transgression. The southern part of Brittany is characterized by sandy beaches and coastal dunes, except locally where a coarse material is provided by erosion of cliffs formed by Pleistocene deposits (head). Nowadays, unconsolidated cliffs are considered as the most significant source of coarse sediments in Brittany (Guilcher et al. 1957, 1990). In the Bay of Brest, the highly weathered of shale cliffs also contribute locally to feed the gravel barriers. In the Bay of Brest, the indentations of the jagged coastline were favorable to the construction of a numerous smale-scale barriers and spits with a high morphological diversity (fig. 2A to 2D). The lenght and the volume of gravel spits in the bay of Brest never exceed $700 \mathrm{~m}$ and $100.000 \mathrm{~m}^{3}$ respectively. Nevertheless, the Sillon de Talbert spit studied in the north of Brittany forms the bigger accumulation reaching $3.2 \mathrm{~km}$ long and sediment volume estimated at $1.23 \times 10^{6} \mathrm{~m}^{3}$ (fig. 2E and 2F). Like most spits on the Channel coasts, formation of the Sillon de Talbert spit began at about 6000 cal.yr.BP when the relative sea-level rise decreased (Morzadec-Kerfourn 1995). This accumulation was enhanced by the presence of many rocky outcrops scattered on a wide seaward-inclined abrasion platform. A few 
hundred metres seaward from the spit, a peat deposit shows at the surface, in which a Final Neolithic archaeological site dating from around 2800 BC was uncovered. This human settlement, then located in the sheltered back-barrier area, bears witness to the considerable movement of the sediment accumulation due to the sea-level rise during the past millennia.

Gravel spits of Brittany belong to "composite gravel beach" type (Carter and Orford 1993; Jennings and Schulmeister 2002). The beachface is characterised by two distinct morphosedimentary parts separated by a break in slope at the mid tide level. The lower part of the beachface is dissipative with a low slope gradient $(0.01 \%)$, and takes the form of a sandy or rocky platform. The upper part of beachface is reflective and corresponds to the gravel barrier itself, mainly composed by sandy-gravel material and a pebble fraction dominating on the crest. Interstitial sandy fraction is important (around 50\%). Slopes values are between $5 \%$ and $17 \%$ according to the different types of sediment assemblages that form the barriers. Gravel spits present generally a single ridge exceeding the high-water-spring-tide level of a few decimeters. Nevertheless, the crest is potentially affected by episodic overwash processes during storm events combined with high-tide level. Some spits present multiple ridge-crest morphology in their distal part related to longshore sediment supply. Behind the spits, back-barrier environments are most often characterised by salt-marshes infilled by sandy to peaty mud.

The coast of Brittany is considered with macrotidal environment, with a maximum tidal ranging from $10.85 \mathrm{~m}$ on the Sillon de Talbert, to $7.6 \mathrm{~m}$ in the Bay of Brest, and $6 \mathrm{~m}$ on the southern coast. Dominant swells mainly come from the west (fig. 1) and show a notable increase during the winter. However, wave conditions vary locally depending on the shallow bathymetry. The spit of Sillon de Talbert appears to be affected by the most energetic swell conditions. The modal height (Hs) is between 1 and $1.5 \mathrm{~m}$, and the modal period (Tpic) between 9 and 10 seconds. During storm events, the wave height can sometimes reach up to $9 \mathrm{~m}$ and the period up to 20 seconds. In these conditions, the Sillon de Talbert acts as a natural barrier against wave attack, offering a sheltered environment for the Bréhat Archipelago to the east and preventing flooding of low-lying Lanros peninsula to the south. The other spits of Brittany are located in more sheltered environments as shown the spits of the bay of Brest. The spits of Dibenn and Bétahon are protected by several shoals and islands. The spit of Linkin is also sheltered from dominant waves by a rocky promontory. Finally, the Bay of Brest is a fetch-limited environment and the waves height never exceed $1 \mathrm{~m}$, whatever the wind conditions (Stéphan, 2011a). According to their general orientation to incident waves, spits are swash- or drift-aligned (fig. 1).

\section{LONG-TERM (10 ${ }^{3}$ YR) EVOLUTION OF GRAVEL SPITS OF BRITTANY}

The lithostratigraphy and biostratigraphy of several back-barrier sediment sequences were examined to reconstruct the late-holocene evolution of four gravel spits located in the bay of Brest. Benthic foraminifera assemblages were analysed to identify the exposure of the salt-marshes and to determine the phases of construction and breakdown of gravel spits. The characterization and the chronology of environmental conditions associated to sedimentary units were improved by using a foraminifera-based transfer function and twenty radiocarbon dates (Stéphan 2011a).

The results show that the stratigraphy of sediment infillings studied at Porzguen and Troaon saltmarshes are transgressives and reveal a similar general pattern of sedimentation. A basal well-humified peat containing reeds remnants (Phragmites australis) and detrital wood fragments overlays a weathered shale preHolocene surface on a maximum thickness of $1.7 \mathrm{~m}$. The age of this basal unit is between 6250 cal.yr BP and 5000 cal.yr BP. Benthic foraminifera assemblages are dominated by Trochammina inflata and, secondarily by Jadammina macrescens and Haplophragmoides wilberti and are attributed by the transfert function to the upper limit of the tide levels. The basal peat units are overlayed by an organic-rich silty-clay $4 \mathrm{~m}$ thick containing root fragments of salt-marsh plants. Foraminifera assemblages are dominated by Trochammina inflata and Jadammina macresens. The contact between the basal peat and this overlying organic mud is gradational and reflect an increase of marine influence in a salt-marsh environment protected by a coastal barrier. At Porzguen marsh, the foraminifra assemblages are homogenous until the actual surface of the mash indicating no significant change of the back-barrier environment and a great stability of the gravel spit during the last millenia. At Troaon marsh, however, this unit contains two thin silty-sand horizons characterized by numerous shell fragments and 
dominated by Haynesina germanica and Elphidium species. These horizons reflect a change in the hydrodynamic conditions of the back-barrier environment related to the erosion of the initial gravel barrier. These coastal changes are not dated precisely but could be related to a phase of high strominess recognised around 3000 cal.yr BP in western part of France. Barriers breakdowns are identified in most late-holocene stratigraphies and correspond to a period of major climatic changes, known as the Bond Cold events (Bond et al. 1997).

At Arun marsh, the sediment infilling has a maximum thickness of $4 \mathrm{~m}$. At the seaward marges of the salt-marsh, the back-barrier sediment sequence is characterised by a set of coarse washover fan deposits interstratified with a silty-clay layers dominated by Jadammina macrescens and Trochammina inflata assemblages. Two barrier erosion and breakdown phases associated to washover deposits are dated around 20001800 cal.yr BP and 1000 cal.yr BP respectively. Here, long-term coastal changes are more important because the spit is exposed to more energetic wave conditions.

On the Loc'h spit, the sedimentary sequence is characterised by a coarse gravels unit corresponding to an initial gravel barrier. Two radiocardon dates obtained from wood fragments located at the bottom and at the top of an underlying sandy-clay organic-rich layer give an age of AD 889-1023 and AD 1023-1157, respectively (Stéphan and Laforge 2013). Analysis of fossil foraminifera assemblages and use of the foraminifera-based transfer function demonstrates that the underlying deposit corresponds to a salt-marsh environment initially protected by an initial gravel barrier. The destruction of this barrier appears to take place from the $11^{\text {th }}-12^{\text {th }}$ centuries and could be related to important variations in sediment supply from periglacial cliffs erosion, associated to extreme storm events. Storm deposits from the end of the early middle ages have been recognized by Giot (1998) and Devoy et al. (1996) in other coastal stratigraphies in the western part of Brittany. This period is obviously characterised by high storminess in the western France.

The back-barrier sediment sequences studied in the bay of Brest indicate that actual gravel spits have recorded a long morphosedimentary evolution over the last millenia. Distinct phases of construction and barrier breakdown were recognized, indicating a variability of storminess and sediment supllies during late-holocene period. However, morphogenic events are not synchronous because the high spatial variability of barrier exposition to the wind-waves in a fetch-limited environment. At Porzguen marsh, sediment sequence highlights a great stability of the gravel spit due to very sheltered conditions.

\section{HISTORICAL EVOLUTION OF GRAVEL SPITS}

Ancient maps of the spits located in south Brittany which have been achieved at the beginning of the $19^{\text {th }}$ century show a trend to landward retreat. In the bay of Brest, a landward migration is also suspected on swash-aligned gravel spits but the rates of migration are difficult to assess. On the Sillon de Talbert, however, coastal changes are more significant. On the first detailed maps drawn in 1666 and 1675, the gravel spit is represented as a welded barrier attached to the islands of the Olone Archipelago. A major morphological change can be seen on the Cassini's map, achieved in the second half of the 18th century. On that map, the Sillon de Talbert is deconnected from the Olone Archipelago by a 200 to $300 \mathrm{~m}$ long breach, transforming the barrier into a spit. This dislocation is dated in the early $18^{\text {th }}$ century, probably due to the violent storm on 26 November 1703. This storm heavily hit the British Isles and western France and is supposed to have cost the lives of between 8,000 and 15,000 people. In England, this storm alone is thought to have killed 1,700 people and to have sunk 12 Royal Navy vessels. It is considered as the most violent storm of the past centuries (Lamb and Frydendahl 2005). The transformation of the initial welded barrier into a spit marked the beginning of a slow cannibalistic process throughout the $19^{\text {th }}$ and $20^{\text {th }}$ centuries, which was accompanied by continuous landward retreat of the spit by rollover. The cannibalistic trend on the Sillon de Talbert is linked to a gradual change in its general direction in relation to incident waves, from a swash-aligned to a more drift-aligned position, leading to an increase in longshore drift. This sediment transport fed the distal end, which widened out through the formation of successive accretion ridges on the lee side of the tip. In return, the proximal end experienced a sediment deficit due to sediment loss by drift. 
Over the last decades, the quantification of the recent mobility of spits in Brittany shows a sediment budget deficit (fig. 3). This sediment depletion is illustrated by cannibalization (e.g. Dibenn spit, fig. 4A), landward retreat by rollover (e.g. Sillon de Talbert spit, fig. 4B) and, in some places, complete destruction of the gravel-dominated spits (e.g. Faou spit, fig. 4C). Located on the southern part of Brittany, Betahon spit is the only case of recent progradation with a mean rate of seaward migration around $0.25 \mathrm{~m}_{\text {.yr }}{ }^{-1}$ (fig. 3). The progradation is related to the construction of a foredune during 1980's by important sediment supply from the west of the bay. Six spits located in the inner parts of the bay of Brest are stable due to their very sheltered position and fetchlimited conditions. It is the case of Porzguen spit which also showed an exceptional stability during the last millennia. Seven spits have experienced a slow landward migration by rollover because of occasional impact of overwash events induicing, in this case, rates of retreat never exceed $0.2 \mathrm{~m} . \mathrm{yr}^{-1}$. Seven spits show macro- and microscale cannibalization trends, reflecting scarcity of the longshore sediment supply. Four spits recorded a rapid rollover with rates of landward migration between 0.25 and $1 \mathrm{~m} . \mathrm{yr}^{-1}$. The highest migration rates are recorded on the Sillon de Talbert (fig.4B). Finally, a case of complete destrcution was observed on Faou spit during last decades. After a rapid landward retreat around 0.6m/yr between 1948 and 2004, two large breaches were openned during the 1970's leading to the gradual lowering of the crest and the sediment dispersion in the back-barrier zone by waves (fig. 4C). Ultimately, the morphological evolutions measured over last decades reveal a scarcity of coarse grain sediment along the Brittany coastline.

\section{THE QUESTION OF SEDIMENT SUPPLY FROM PERIGLACIAL CLIFF EROSION AND SEDIMENT BUDGET}

The recent mobility of the gravel spits highlights the lack of significant sediment input. Because the unconsolidated cliffs formed by periglacial deposits (head) are nowadays the main sediment sources of coarse sediment to the coast, the recent volumes provided by their erosion were assessed closed to three study areas. Cliff erosion rates were determined near Betahon and Dibenn spits and in the bay of Caro (Bay of Brest) by analysing changes of the backscar (cliff-top) plotted from aerial photographs. Volumes were calculated as Shuisky and Schwartz (1983) and have been estimated at $570 \mathrm{~m}^{3} \cdot \mathrm{yr}^{-1}$ in the bay of Betahon. This supply explains the recent seaward migration of the spit. However, the bay of Betahon appears to be an exception at regional scale. Generally in Brittany, the retreat of unconsolidated cliffs is slow. For instance, erosion of Dibenn cliffs provides a sediment volume estimated at $20 \mathrm{~m}^{3} . \mathrm{yr}^{-1}$ which is not sufficient to prevent the cannibalization of the spit. In the bay of Brest, taking the exemple of Caro studied site, the maxima of volumes of sediment supply provided by unconsolidated cliff erosion is estimated at only $48 \mathrm{~m}^{3} \cdot \mathrm{yr}^{-1}$.

Gravel barriers are formed by fossil deposits which have within a context of sediment abundance and a decreasing of Holocene of sea-level rise around $6000 \mathrm{cal} . y r$ BP. In the eastern part of the Channel, authors have shown that a large amount of the gravel accumulations were originated from sea erosion of a periglacial head deposits present on the continental shelf during the post-glacial transgression (Bray et al. 1995). This sediment source was gradually depleted during the last milleniums because of the decrease of the relative sea-level rise. On Nova Scotia coast (Canada), the authors have explained the erosion of gravel barrier and spit by the absence of major sea-level fluctuations during the past millennia (Forbes et al. 1995; Orford et al. 2002). In that context, no sediment supply on the foreshore by cliff erosion is realised. Stéphan (2011c) showed that in western Brittany (Bay of Brest), rates of relative sea-level rise have gradually declined since 2700 cal.yr.BP and are below 1 mm.yr-1 for the last millennium. This rise of sea-level is not sufficient to enable a widespread of large amout of sediments. Field observations indicate that the base of unconsolided cliffs is nowdays rarely reached by waves attack (Stéphan 2011a). Furthermore, the presence of a large platform in front of the current cliffs promotes the dissipation of wave energy before it reaches the foot of the cliff.

\section{IMPACT OF HUMAN FORCINGS}

In Brittany, anthropogenic forcing have often been overstated to explain coastal erosion of gravel barriers. Sediment mining has played a role only in places. Pebbles were only extracted for industrial use in the Bay of Audierne during the Second World War by the Wehrmacht Todt Organisation, to built the german 
defense (Atlantic Wall). In this area, sediment extraction represented a volume of around $1.10^{6} \mathrm{~m}^{3}$. For the Sillon de Talbert, no data is available to estimate the volumes extracted, but historical documents indicate that during the $18^{\text {th }}$ and $19^{\text {th }}$ centuries, the barrier was also used for pebble mining. However, this practice was prohibited in the early $20^{\text {th }}$ century. In the bay of Brest, sediment mining undertaken during the 1960 's by oyster-farming activity has caused a reduction of $10 \%$ and $50 \%$ of the total sediment volumes of Mengleuz and Kersanton spits respectively.

Jetties constructed downdrift have led to a reduction of longshore sediment supply towards the Troaon, Auberlac'h (fig. 2A) and Mengleuz (fig 2C) spits. This process is explaining cannibalization of Troaon spit and the erosion of Mengleuz and Auberlac'h spits. On the Sillon de Talbert, following the 5 April 1962 storm, major defense management of the spit was undertaken. In 1967, the breaches in the dune were artificially plugged. A riprap jetty was built between 1974 and 1982 in order to protect the dune section and to trap eastward sediment transit. A frontal rocky armor was also built at the crest of the spit over a distance of $1500 \mathrm{~m}$ to prevent overwash and rollover processes. However, the armor perturbated the natural self-organisation of the spit and increased wave reflection causing the erosion of the lower beachface. During winter 1989-90, despite the existence of this defense structure, serie of storms caused considerable lowering of the barrier, the formation of new breaches and the retreat of the spit. In 2004, the main part of the frontal armor was removed by local authorities (fig. 2G and $2 \mathrm{H})$.

\section{MORPHODYNAMIC BEHAVIOURS OF GRAVEL BARRIERS AT MID-TERM}

Natural forcing, such as waves and tide, was analysed between 1953 and 2011 in the bay of Brest (Stéphan 2011c) and between 1979 and 2011 on the Sillon de Talbert spit (Stéphan et al. 2012). This analysis was based on the reconstruction of high water levels inducing crest erosion and/or overwash processes. On the Sillon de Talbert spit, the rate of landward retreat by rollover is strongly controlled by overwash frequency and magnitude. Between 1979 and 2010, Unit 1 (see on fig. 4B) was affected by very few overwash episodes, which explains the stability of this spit section from the 1970's. Unit 2 was more frequently affected by overwash, in particular after the 1989-90 winter storms which created two main breaches in this section. At the same time, the increase of overwash events during the 1990's can also be explained by the lowering of the crest. Units 3 and 4 showed more frequent overwash events between 1979 and 2010. The most severe ones were generated by 198990 winter storms and the 10 March 2008 Johanna storm. During these two storm periods, landward retreat by sluicing overwash reached $-15 \mathrm{~m}$ and $-13.2 \mathrm{~m}$ for unit 3 and $-17 \mathrm{~m}$ and $-14.7 \mathrm{~m}$ for Unit 4 . Several secondary discrete overwash events were also recorded during the spit's low mobility phases.

In the bay of Brest, spit mobility over the last decades was not so clearly linked to overwash events. Nevertheless, three overwash regimes are identified according to barrier alignment (fig. 5). A first overwash regime (R1), characterized by low frequency and high magnitude of overwash events, is driving swash-aligned gravel spit processes causing slow landward retreat by rollover. A second regime (R2), defined by high frequency and low magnitude of overwash events, is drinving drift-aligned gravel spit evolution dominated by relative stability and cannibalization. A third regime (R3) concerns swash-aligned spits frequently reached by energetic overwash events causing rapid landward retreat by rollover or complete destruction of spits.

\section{SHORT-TERM EVOLUTIONS : BARRIER RESPONSES TO EXTREME STORM EVENTS}

Between 2002 to 2012, morphological evolution of five gravel barriers affected by erosion was annualy surveyed using DGPS. The role played by overwash dynamic was also studied by analysing hydrodynamic conditions. Results show different pluri-annual morphogenetic phases. On Sillon de Talbert spit, the major storm event of 10 Marsh 2008 caused a barrier average retreat up to $10 \mathrm{~m}$ and a crest lowering reaching $-1.5 \mathrm{~m}$. Volume of removed sediments due to barrier retreat were estimated to $120,000 \mathrm{~m}^{3}(10 \%$ of the total volume of the spit). The morphogenetic impact of this extreme event is explained by the conjunction of high spring tide levels and energetic wave conditions ( $\mathrm{hs}=9.5 \mathrm{~m}$ ) inducing high surge level on the coast. The occurrence of this event is between 50 and 100 years on the coast of Brittany. This sluicing overwash phase occurred after a period 
of stability related to a low morphogenetic condition between 2002 and 2007. After the Johanna storm event, crestal overtoppping phase corresponding to the progressive spit recovery was recorded. The "ridge rebuilding activity” as defined by Orford (2011), was undertaken between March 2008 and September 2012, showing the great resilience of the barrier. During this post-storm recovery period, the average of crest elevation was up to 1 $\mathrm{m}$, reaching locally $2 \mathrm{~m}$. These different morphogenetic phases were also recognised on other coastal areas along the Brittany coastline (Suanez et al. 2011; Suanez and Stéphan 2011). In contrast, in the bay of Brest, the recover of spits and barriers after the 10 March 2008 storm event was not so obvious. For instance, Loc'h spit showed a tendency of erosion for the whole period of measurements, especially since the 10 March 2008 Johanna storm (Stéphan and Laforge 2013) (fig 6).

\section{MANAgMENT STRATEGIES OF GRAVEL SPITS}

After several decades of coastal erosion management strategy mainly based on hard defense structures, the Sillon de Talbert has experienced since 2001 a new management policy provided by the 'Conservatoire $\mathrm{du}$ Littoral'. The principal goal is not let the spit retreating naturally while attempting to prevent its breaching. In October 2004, a large part of the frontal armor located on the Units 2 and 3 was removed (fig. 2G and 2H). The riprap was crushed and the material was deposited on the rear of the spit, forming three embankments in a way to slow down the landward retreat barrier. After the major morphological changes caused by the Johanna storm, human interventions were only restricted to plug breaches in the dune, and to set up new fences in a way to recover dune morphology. It denotes a radical change in terms of coastal management strategy facing erosion in France. The 'Conservatoire du Littoral' is a national organisation in charge of the acquisition of coastal lands for there preservation. Since the 2000's, the 'Conservatoire du Littoral' initiated a policy of acquisition of low-lying coastal lands threatened to flooding, situated on the rear of the Sillon de Talbert spit. This policy promotes the strategic withdrawal of human settlements. In the bay of Brest, a managment stragegy of gravel spits and backbarrier salt-marshes is establishing by local authorities (Stéphan et al. 2012) in order to protect barriers affected by erosion and restore ecological value of marsh environments. Gravel spits are also considered as geological heritage that must be protected from any human forcing using management plans.

\section{RÉFÉRENCES}

Bond G, Showers W, Cheseby M et al (1997) A pervasive millennial-scale cycle in North Atlantic Holocene and glacial climates. Science 278:257-126

Bray MJ (1995) Littoral cell definition and budgets for central southern England. J Coastal Res 11(2):381-400

Carter RWG, Orford JD (1993) The morphodynamics of coarse clastic beaches and barriers: a short- and longterm perspective. J Coastal Res SI 15:158-179

Devoy RJN, Delaney C, Carter RWG et al (1996) Coastal stratigraphies as indicators of environnemental changes upon European Atlantic coasts in the Late Holocene. J Coastal Res 12:564-588

Forbes DL, Orford JD, Carter RWG et al (1995) Morphodynamic evolution, self-organisation, and instability of coarse-clastic barriers on paraglacial coast. Mar Geol 126(1-4):63-85

Giot PR (1998) La dune ancienne de la baie d'Audierne. Norois 45:487-494

Guilcher A, Vallantin P, Angrand JP et al (1957) Les cordons littoraux de la rade de Brest. Cahiers Océanographiques 1:21-54 
Guilcher A, Bodéré JC, Hallégouët B (1990) Coastal evolution in western, southwestern and northern Brittany as a regional test of impact of sea level rise. J Coastal Res SI9:67-90

Jennings R, Shulmeister J (2002) A field based classification scheme for gravel beaches. Mar Geol 186(34):211-228

Lamb HH, Frydendahl K (2005) Historic storms of the North Sea, British Isles and Northwest Europe. Cambridge University Press, Cambridge

Morzadec-Kerfourn MT (1995) Coastline changes in the Armorican Massif (France) during the Holocene. J Coastal Res SI17:197-203

Orford JD, Forbes DL, Jennings SC (2002) Organisational controls, typologies and time scales of paraglacial gravel-dominated coastal systems. Geomorphology 48:51-85

Orford JD (2011) Gravel-Dominated coastal barrier reorganisation variability as a function of coastal susceptibility and barrier resilience. Coastal Sediments ’11:1257-1270

Reimer PJ, Baillie MGL, Bard E et al (2009) IntCal09 and Marine09 Radiocarbon Age Calibration Curves, 050,000 Years cal.BP. Radiocarbon 51:1111-1150

Shuisky YD, Schwartz ML (1983) Basic principles of sediment budget study in the coastal zone. Shore and Beach 51(1):34-40

Stéphan P (2011a) Colmatage sédimentaire des marais maritimes et variations relatives du niveau marin au cours des 6000 dernières années en rade de Brest (Finistère). Norois 220:9-37

Stéphan P (2011b) - Les flèches de galets de Bretagne : évolution passée, présente et future. L’Harmattan, Paris

Stéphan P (2011c) Quelques données nouvelles sur la mobilité récente et le bilan sédimentaire des flèches de galets de Bretagne. Géomorphologie : relief, processus, environnement 2:205-232

Stéphan P, Suanez S, Fichaut B (2012) Long-term morphodynamic evolution of the Sillon de Talbert gravel barrier spit, Brittany, France. Shore \& Beach 80 (1):19-36

Stéphan P, Laforge M (2013) Mise au point sur l'évolution géomorphologique et le devenir des flèches de galets du Loc’h de Landévennec (Bretagne, France). Géomorphologie : relief, processus, environnement 2:81-98

Stuiver M, Reimer PJ (1993) Extended 14C data base and revised CALIB.3.0. 14C age calibration program. Radiocarbon 35:215-230

Suanez S, Fichaut B, Magne R et al (2011) Changements morphologiques et budget sédimentaire des formes fuyantes en queue de comète de l'archipel de Molène (Bretagne, France). Géomorphologie : relief, processus, environnement 2:187-204

Suanez S, Stéphan P (2011) Effects of natural and human forcing on mesoscale shoreline dynamics of SaintMichel-en-Grève Bay (Brittany, France). Shore \& Beach 79 (2):19-38 
FIGURES

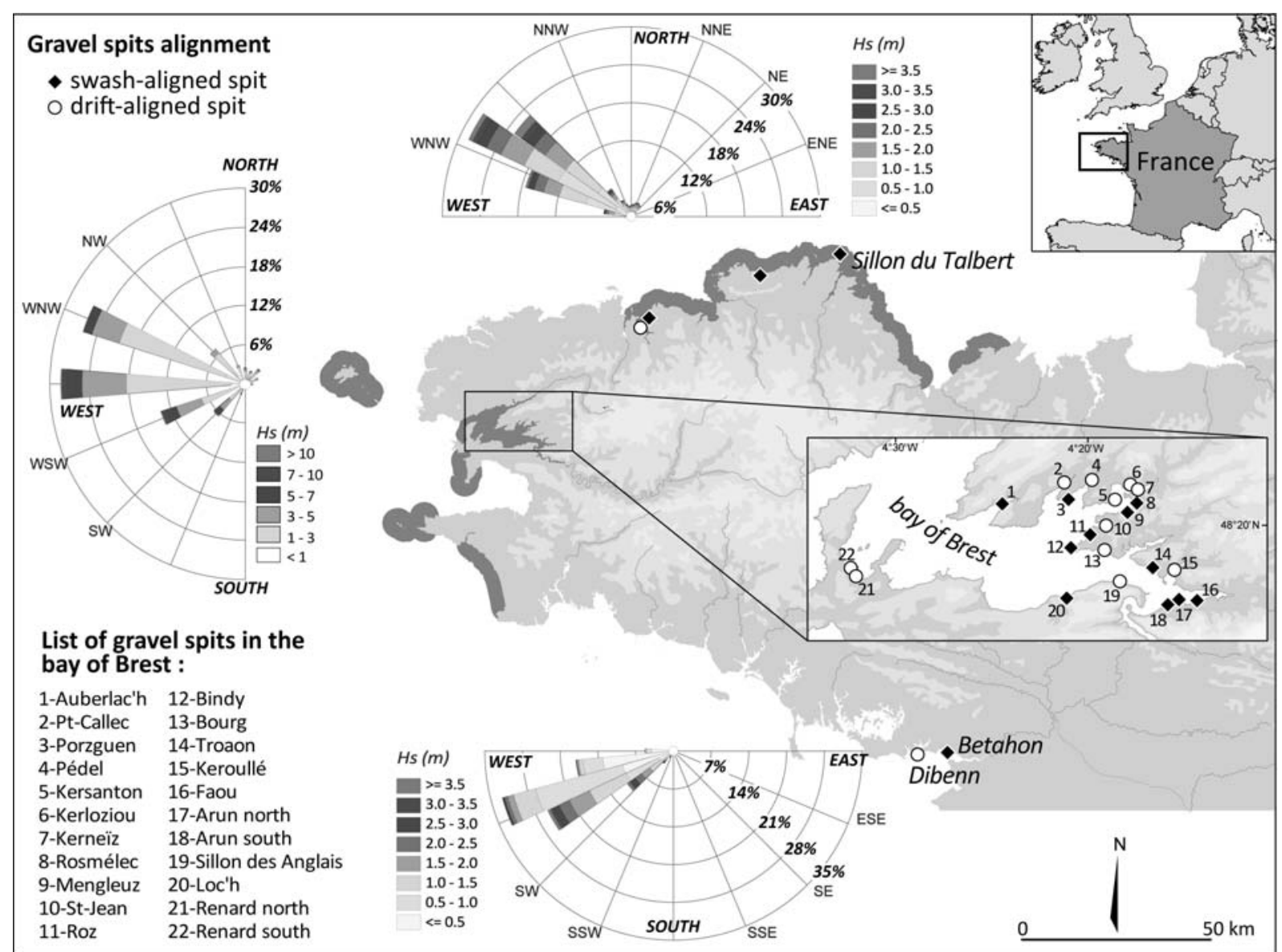

Fig. 1 Location maps of gravel beaches (shoreline in grey color) and spits (points) along the west coast of France. Wave climate of the northern, the southern and the western part of Brittany obtained by numerical run model over the period 1979-2002 (source: LNHE-EDF and CETMEF-Brest laboratory) 

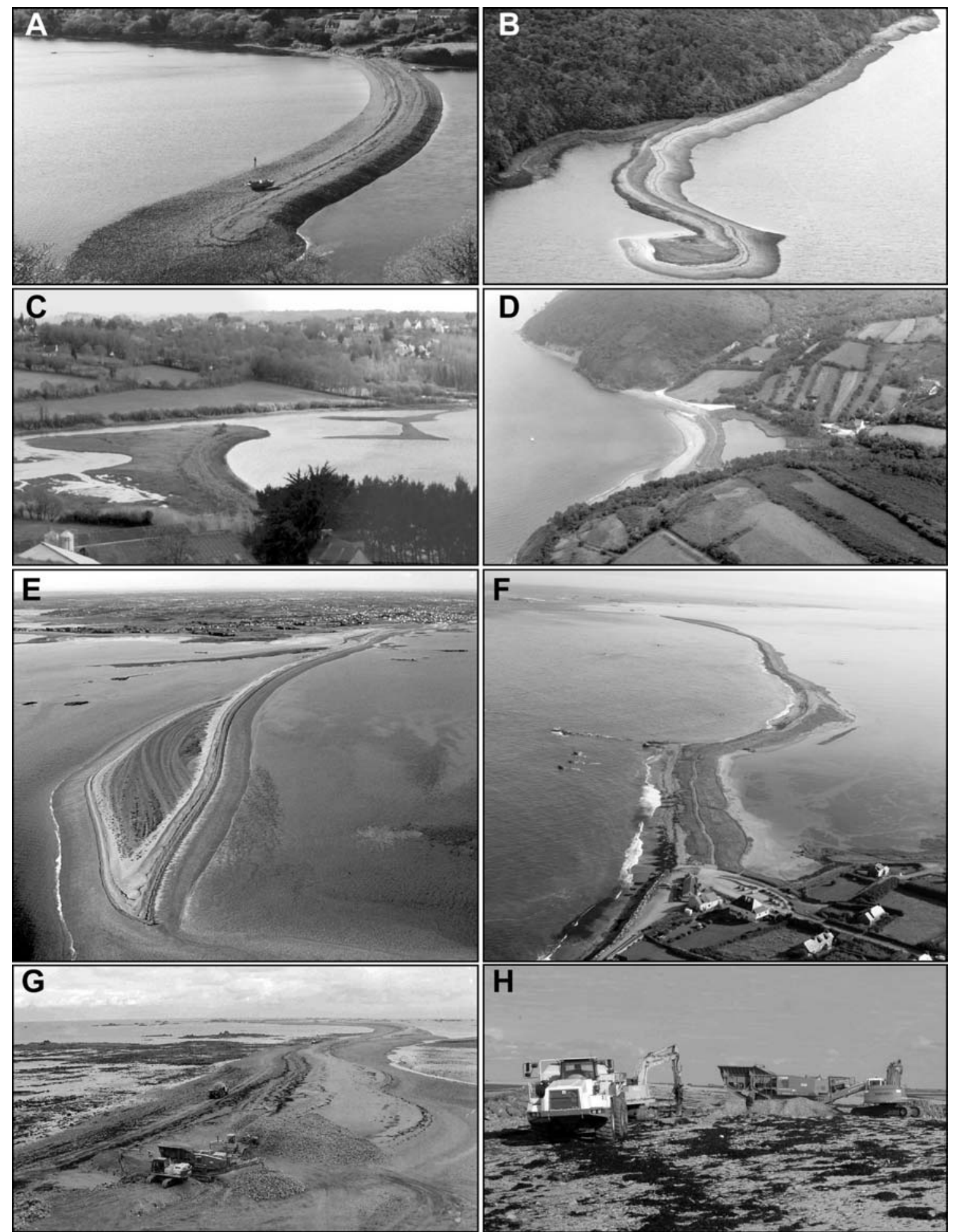

Fig. 2 a Auberlac'h mid-bay spit, b Sillon des Anglais spit, c Rosmélec and Mengleuz opposite spits, d Loc'h spit, e Distal end of Sillon de Talbert spit, $\mathbf{f}$ Proximal dune section of Sillon de Talbert spit, $\mathbf{g} \mathbf{h}$ Removing of the frontal armor located on units 2 and 3 of the Sillon de Talbert spit in October 2004 


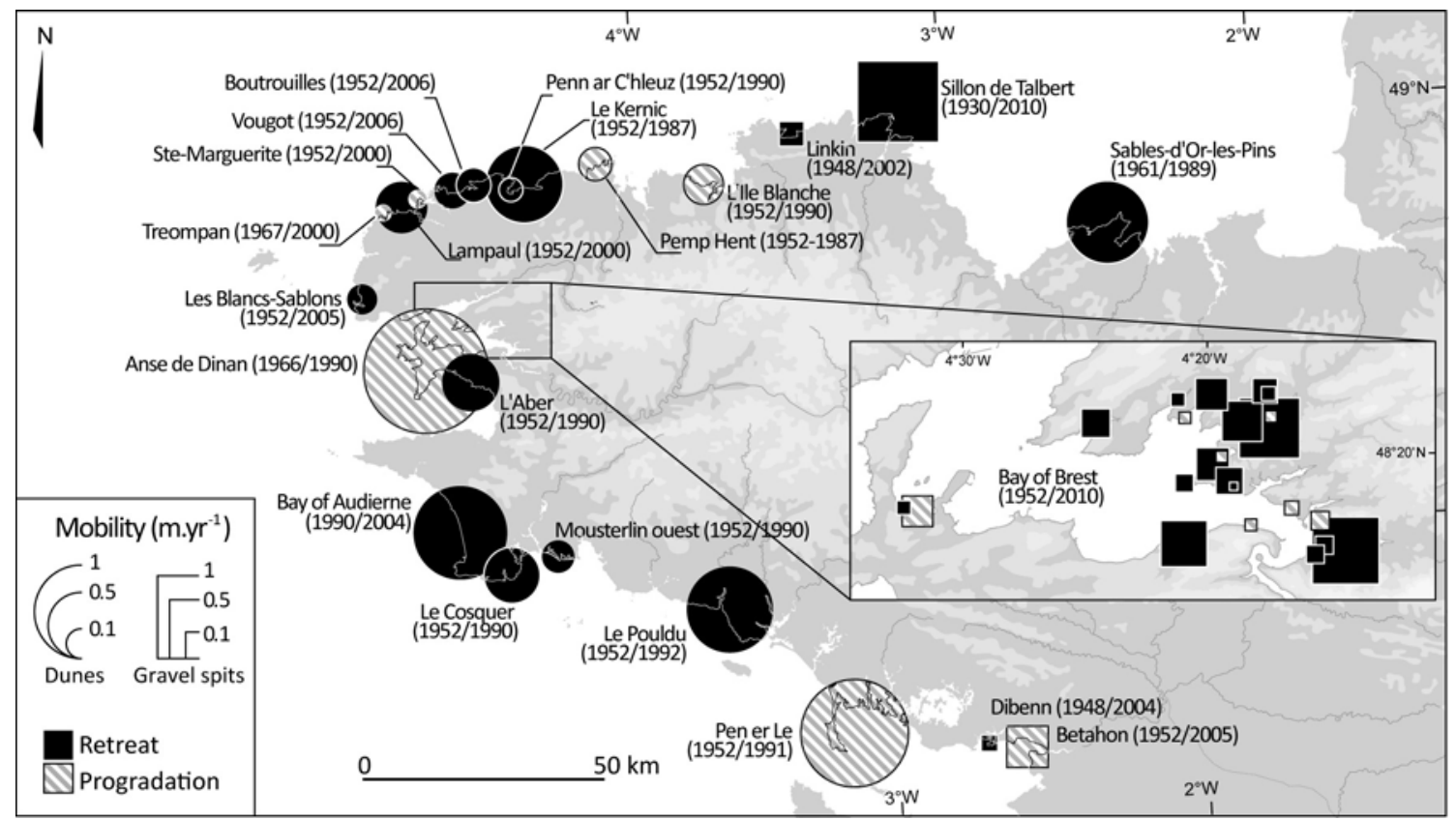

Fig. 3 Synthesis of data available on recent mobility of coastal barriers of Brittany (Stéphan, 2011c) 


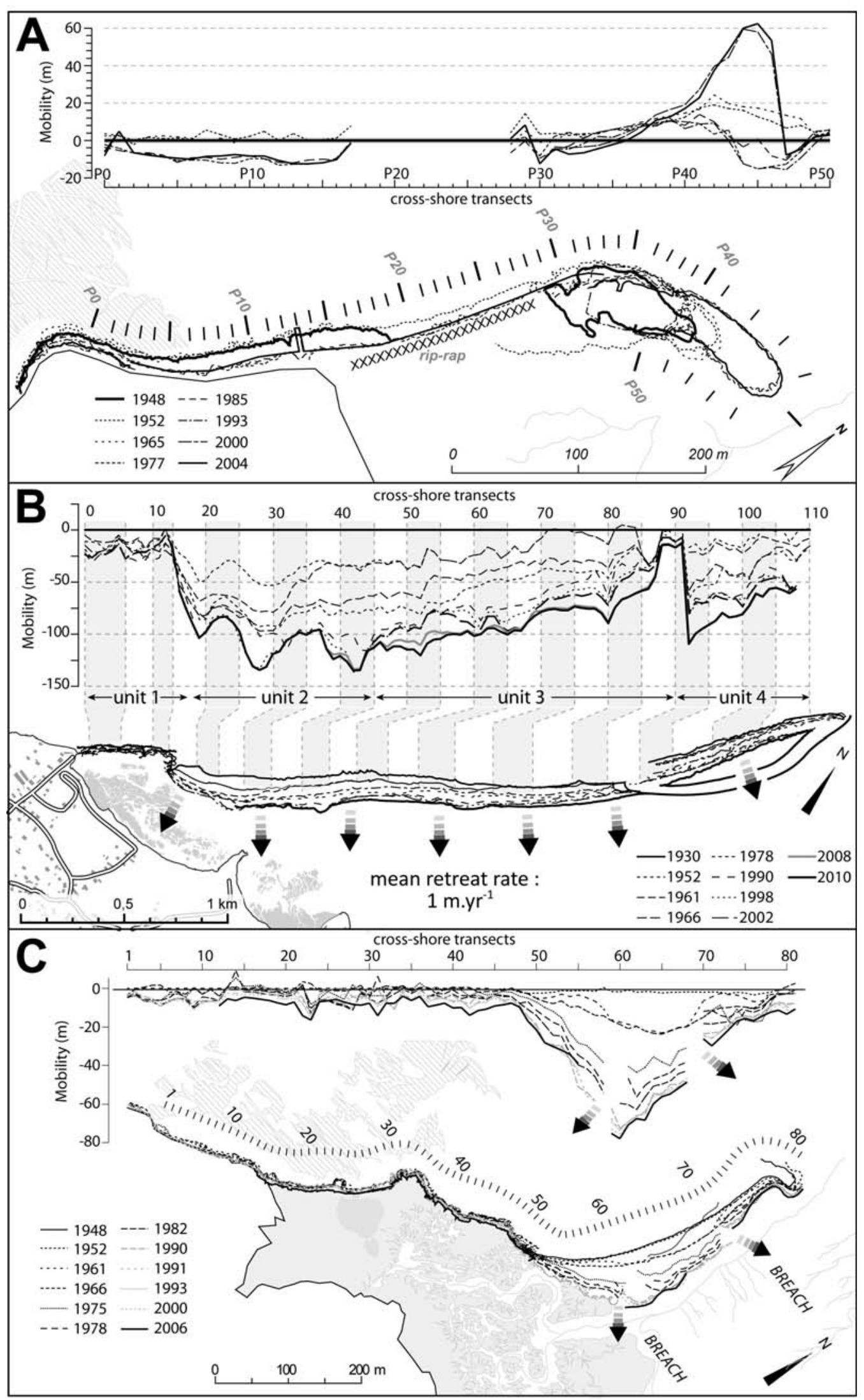

Fig. 4 Recent mobility of some gravel spits in Brittany, a Cannibalisation of Dibenn spit (Stéphan, 2011c), b Retreat by rapid rollover of Sillon de Talbert spit (Stéphan et al., 2012), c Dislocation of Faou spit (Stéphan, 2011c) 


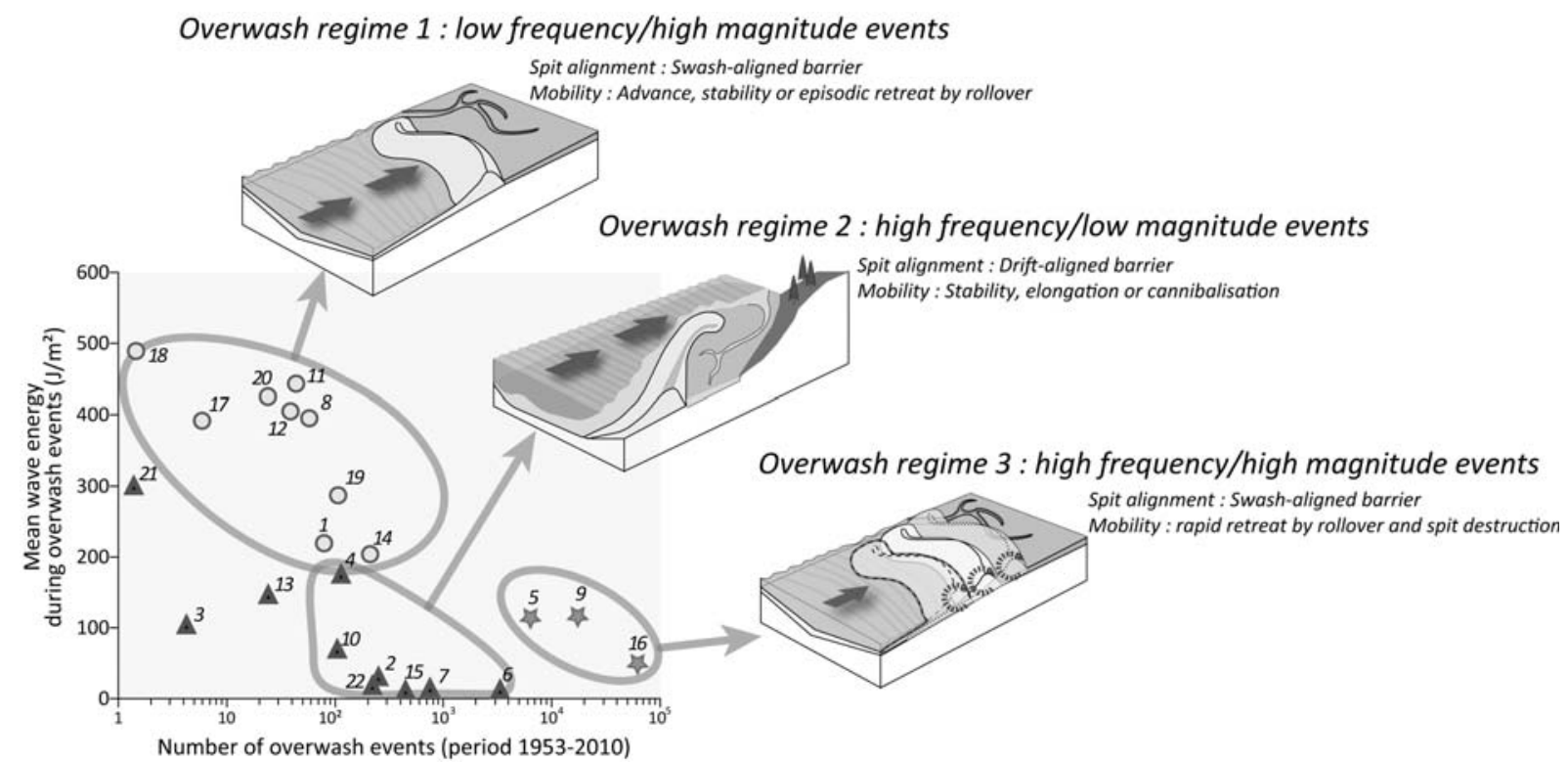

Fig. 5 Overwash regimes and morphodynamic behaviours according to gravel-spits alignment. Numbers on the graph refer to the list of gravel spits in the bay of Brest (see Fig. 1)

\section{Fig. 6}

